\title{
Gıdalarda Escherichia Coli O157:H7 Yaygınlığının Riskleri ve
}

\author{
Kontrolü \\ Escherichia Coli 0157: H7 Prevalence and Control in Foods \\ Nalan TURGUT ${ }^{1}$ A,B,C,D,E,F,G $\mathbf{G}_{\mathbb{C}}$ \\ ${ }^{1}$ Aydın Adnan Menderes Üniversitesi, Ziraat Fakültesi, Aydın, Türkiye
}

ÖZ

Toplum sağlığı açısından risk taşıyan ve gıda kaynaklı bir patojen olan Escherichia coli O157:H7 önemli ve tehlikeli mikroorganizmalardan birisidir. Patojenin bulaşma yollarının bilinmesi, yayılmayı önleyici tedbirlerin tam olarak anlaşılması ve bulaşma riskinin azalma yollarının tespiti insanların bu patojenden korumada en önemli kriterlerdendir. Bu çalışmada patojenin tam olarak kaynaklarının bilinmesi, bulaşma yolları ve yayılmasını engellemede güncel çalışmaları kullanarak kişilerin bu patojen kaynaklı rahatsızlıkların önüne geçilmesine yardımcı olmak amaçlanmıştır. Konuyla ilgili olarak son dönemlerde yapılmış olan çalışmalar incelendiğinde etmenin bulaşma yollarına dikkat çekilmiş, özellikle iyi pişirilmemiş et ürünlerinin tüketimi, pastörize edilmemiş süt tüketimi, kontamine olmuş havuz ya da göl sularında yüzmek dünyada görülen enfeksiyonların sebebi olmasından dolayı bulaşma riskini ortadan kaldırmak ve hastalıktan korunmaya yardımcı olmak adına yaşam kalitesini artırıcı etkisi bulunan konular üzerinde önem kazanmıştır.

Anahtar Kelimeler: E. coli O157:H7, Gıda, Sağl1k, Kontaminasyon.

\section{ABSTRACT}

One of the most important food-borne pathogen is Escherichia coli O157:H7 and results a public health risk. Information of transmission of the pathogen, understanding the preventation mechanism, and knowing how to reduce the risk of transmission are the most important criteria for protecting people from this pathogen. The aim of this study to know the exact sources of this pathogen and to help prevent the pathogen-related diseases by using the current studies used in preventing transmission and spreading. In recent years, when the research on the topic are discussed, the ways of transmitting E. Coli O157: $\mathrm{H7}$ has been noted, in particular the consumption of poorly cooked meat and meat products, unpasteurized milk, swimming in polluted pools or lake waters that pose a risk of contamination due to infections around the World. Improving the quality of life with a view to eliminating the disease and helping to avoid it has become increasingly necessary.

Key Words: E. coli O157:H7, Food, Health,

\section{GİRIŞ}

Yaşam boyunca beslenme konusu halk sağlığını etkileyen en önemli faktörler arasında yer almaktadır. Bireylerin daha uzun, daha kaliteli ve sağlıklı bir hayat sürdürebilmeleri adına göstermiş oldukları gayret içerisinde, beslenme alışkanlıkları ve daha iyi beslenmeleri konusunda tercih ettikleri gıdalara dikkat etmeleri gereken önemli konuların başında gelmektedir. Özellikle taze meyve ve sebzeler besin içeriği ve ekonomik olmaları sebebiyle insan beslenmesi açısından oldukça önemli bir yere sahiptir. Gelişmiş ülkelerde minimal işlem görmüş meyve ve sebzelerin tüketimleri yaygındır, gelişmekte olan ülkelerde ise hem taze olmaları hem de kolay bulunabilmeleri sebebiyle tüketimleri her geçen yıl artış göstermektedir 
(1). Yapılan araştırmalar gösteriyor ki, insan beslenmesi için kolaylık sağlayan tüketimi hazır olan gidalarda Staphylococcus aureus, Escherichia coli, Salmonella spp., Clostridium perfringens, Bacillus cereus ve Listeria monocytogenes gibi pek çok patojen bulunabilmektedir. Amerika Birleşik Devletleri'nin farklı eyaletlerinde marul ve ıspanak tüketimine bağlı olarak gelişen gastroenterit salgınlar meydana gelmiş ve salgınların nedeni olarak da Escherichia coli O157:H7 bildirilmiştir (2).

Escherichia coli (E.coli), genel anlamda bakteri biyolojisinin anlaşılabilmesi için en fazla çalışılan ve firsatçı patojen olarak bilinen bir mikrobiyolojik modeldir (3). Escherichia coli kalın bağırsak florası içerisinde varlığını devam ettiren fakültatif anaerob bakterilerdendir (4). Enterobacteriaceae familyası içerisinde Escherichia genusuna bağlı gram negatif bakteri olduğundan endospor oluşturmaz bu sebeple pastörizasyon ya da kaynatma işlemi ile ölür $(4,5,6)$. E. coli, yaklaşık 2-6 $\mu \mathrm{m}$ boyunda ve 1-1,5 $\mu \mathrm{m}$ enindedir. Düz çomak şeklinde, uçları yuvarlaktır. $(4,7)$ Peritrik kamçıları ile hareket eder fakat yavaş hareketlidirler ayrıca hareketsiz suşları da vardır. Bakteriyolojik boyalarla iyi boyanır, bazı suşları kapsüllüdür. E. coli suşlarının pek çoğu fimbria oluşturmaktadır. Hareketli suşlarda bulunan K antijenlerinden bazıları ile oluşan fimbrialardan hücre duvarında bulunan somatik $\mathrm{O}$ antijenleri, meydana gelen enfeksiyonların patogenezinde oldukça etkilidirler (5). Enterohemorajik Escherichia coli (EHEC) insan ve hayvanlarda hastağa sebep olan E. coli patotiplerindendir ve bilinen E. coli tipleri içerisinde ölümle sonuçlanabilecek gıda kaynaklı enfeksiyonlardan sorumlu tutulan O157:H7 serotipini içermektedir. E. coli O157:H7 formu en zararlısı olarak bilinir, insanlarda kolon mukoza hücrelerinin sitolizine (hemorajik kolitis (HC), hemolitik üremik sendroma (HUS) ve trombotik trombositopenik purpuraya (TTP) neden olmaktadır ve toplum sağlığını tehdit etmektedir (8). EHEC'in en yaygın örneği olarak bilinen O157:H7, enfeksiyonun oluşmasında etkin olan verotoksin Shigella dysenteriae tip 1'in oluşturduğu toksin ile benzerlik göstermesi sebebiyle Shiga benzeri toksin (Shiga like toxin-SLT) olarak da adlandırılan vero sitotoxin veya verotoxin (VT) üretimi ile bilinmektedir. Shiga toksini üretme özelliği Shigella dysenteriae'dan kaynaklanmaktadır $(9,10,11)$. EHEC, gelişmiş ülkelerde kanlı ishal gibi çok ciddi hastalıklara yol açan E. coli grupları içerisinde yer almaktadır $(12,13,14)$. EHEC'in elliden fazla serotipinin olduğu bilinmektedir ve en yaygın tipi E. coli O157:H7'dir (15).

\section{Gıdalarda Escherichia coli O157:H7’nin Yayılması, Taşınması ve Çoğalması}

E. coli O157:H7 serotipinin kaynağ1 olarak pek çok görüş bildirilse de bulaşmada süt inekleri başta olmak üzere, özellikle sığırların etkin derecede rolü olduğu bilinmektedir. Sığırların et olarak tüketilen kaslarında bu bakteriye rastlanmazken E. coli O157:H7 ile enfekteli bir sığır dışkısı ya da bağırsakla temas eden ette hastalığın bulaşması ile ilgili risk ortamı oluşmaktadır. Oluşabilecek enfeksiyonlarla ilgili olarak birinci derecede risk grubunda bulunan sığırların dışındaki diğer hayvanlar ise E. coli O157:H7 için vektör veya hastalık kaynağı olarak bilinmektedir (16). Görülen enfeksiyonların çoğunun sebebinin iyi pişirilmemiş et ve et ürünlerinden ve ayrıca pastörize edilmemiş sütten kaynaklandığ $(17,18,19)$. E. coli O157:H7'nin prevalansında coğrafi konum, hayvanın türü, yaşı ve cinsi, mevsimler etkili olabilmektedir ve ayrıca yaz aylarında prevalansın daha fazla olduğu bildirilmektedir (20). 1996 yılında 28 Mayıs - 27 Haziran tarihleri arasında A.B.D’nin Connecticut ve Illinois eyaletlerinde yürütülmüş olan çalışmada mesclun (küçük kırmızı ve 
yeşil yaprak marulların bir karışımı) marul tüketimi ile Escherichia coli O157:H7 salgını ve meydana gelen enfeksiyonların kaynağını belirlemek amacıyla araştırmalar yapılmış elde edilen sonuçlar göstermiştir ki iki eyalette de hastalığın \%95 oranında mesclun marul tüketimiyle bulaşmış olduğu ve hastalık kaynağının da üretimin yapıldığı tarlalarının yakınında bulunan hayvan çiftliklerinin olduğu tespit edilmiştir. Ayrıca bu çalışma marul üretimi sırasında kontaminasyonun potansiyel olarak meydana gelebileceği ve marulun mikrobiyal patojenler tarafindan kontamine olmasına katkıda bulunabilecek mevcut üretim uygulamaları hakkındaki fikir vermiş olup marul üretim uygulamalarının mikrobiyolojik güvenlik açısından izlenilmesi gerektiği kanaatine varılmıştır (21). Singapur'da ticari olarak satılan ve yaygın olarak tüketilen taze sebze ve meyvelerin mikrobiyolojik kalitesini, bu ürünlerin tüketimiyle ilişkili potansiyel sağlık tehlikeleri hakkında bilgi sağlamak amacıyla yürütülen çalışmada süpermarketlerden ve yerel pazarlardan toplanan toplam 125 örnek aerobik, mezofilik ve psikrotrofik bakteri sayıları açısından test edilmiştir. 100 örnekde maya ve küf sayımı, koliform sayımı, Escherichia coli O157:H7 ve Salmonella spp. açısından aerobik, mezofilik sayımlar 1.6 ile $9.1 \mathrm{log}$ cfu / g arasında değişmekte olup, portakal ve fasulye filizi için sırasıyla en düşük ve en yüksek sayımlar kaydedilmiştir. En yüksek koliform seviyesi fasulye filizi ve taze kesilmiş salata örneklerinde bulunurken, örneklerin \%50'sinin 5'ten fazla log cfu / g içerdiği tespit edilmiştir. Fasulye filizlerinde ve taze kesilmiş salatalarda koliform sayılarında olduğu gibi, yüksek seviyede maya ve küf sayıları elde edilmiştir. Taze kesilmiş salatalar 4.9 log cfu / g'lık en yüksek ortalama ile psikrotrofik plaka sayısına sahip olarak kaydedilmiştir. Buna rağmen E. coli O157:H7 veya Salmonella spp. analiz edilen meyve ve sebzelerde, özellikle fasulye filizi ve taze kesilmiş salatada yüksek bakteri sayımlarında tespit edilmemiştir. $\mathrm{Bu}$ sayede Singapur'da satılan taze ürünlerin mikrobiyolojik kalitesini iyileştirmek için etkili kontrol önlemlerinin uygulanması gerektiği kanısına varılmıştır (22). Son yıllarda gıda kaynaklı hastalıkların epidemiyolojisinin hızla değişim göstermesine, yeni tanınan gıda kaynaklı patojenlerin ortaya çıkması da eklenince bu durum ciddi bir boyut kazanmıştır. Escherichia coli O157:H7 ve diğer enterohemorajik E. coli, Salmonella typhimurium Definitive Type 104, Cryptosporidium parvum, Cyclospora cayetanensis, Arcobacter butzleri ve Helicobacter pyco dahil olmak üzere önemli gıda kaynaklı patojenler yeni ortaya çıkmıştır. Ayrıca yıllardan beri Campylobacter jejuni ve Listeria monocytogenes patojen olarak kabul edilmiş son yirmi yıllık dönemde ise gıda kaynaklı patojen olduğu kabul görmüştür (23).

2011 yılı Mayıs ayı sonu itibariyle Almanya'da görülen salgında etmenle bulaşık salatalık tüketimi sebebiyle gelişen ve 1000 kişinin etkilendiği olumsuz olay sonucunda 28 Mayıs tarihi itibariyle 10 kişinin yaşamını yitirdiği bildirilmiştir. Son olarak da 2018 yılı nisan ayında ilk olarak ABD'nin Arizona eyaletinde başlamış ve 35 eyalete yayılmış olan salgında CDC' ye (ABD Hastalık Kontrol ve Önleme Merkezleri) göre toplam 195 kişi bu durumdan etkilenmiş bu kişiler arasından 89 kişi hastaneye yatmış ve 5 kişinin hayatını kaybettiği kayıtlara geçmiştir (24). Shiga toksini üreten E. coli O157:H7 ile sığır eti arasında meydana gelen enfeksiyonlar bakımından muhtemel ilişki kuvvetli olup ve diğer gıda ürünlerinden daha sık ilişkilendirilmiş olsa bile, bunun yanında ciddi salgınların etmenle bulaşı önceden paketlenmiş ıspanak, turp ve bu ürünlerin tüketimi ile olabildiği de bildirilmiştir. Benzer şekilde, Salmonella enfeksiyonları esas olarak hayvansal kaynaklı gıdaların tüketimi ile bağlantılı olmasına rağmen yürütülen bu çalışma ile birçok salgın kontamine taze ürünlere kadar takip edilmiştir (25). 
Dünyada Escherichia coli O157:H7 enfeksiyonu pek çok ülkede görülebilmektedir. Senelik 100,000'de 8 insidans oran ile Kuzey Avrupa, Kanada, ABD, Arjantin ve Japonya gibi ülkelerde en fazla karşılaşılmaktadır. 1993 yılında İtalya'da E. coli O157:H7 salgını meydana gelmiş ve 1997 yılına kadar 196 HUS vakası kayıtlara geçmiştir. Ancak karşılaşılan HUS insidans oranının İngiltere, Almanya ve diğer Avrupa ülkelerine kıyasla 4-5 kat daha az olduğu belirtilmiştir (26). 1995 yılının sonbahar mevsiminde İsveç'te yaklaşı 100 kişiyi etkileyen salgında, serotip O157: H7 verotoksin üreten E. coli (VTEC) varlığı açısından araştırılmış ilk enterohemorajik Escherichia coli O157: H7 salgınları kayıtlara geçmiştir. Çalışmanın yürütüldüğ̈ sırada diğer ülkelerde meydana gelen salgınlardan, sığırların bu bakterileri taşıyabileceği ve birçok durumda enfeksiyonun kaynağını oluşturduğu bilinmektedir. Bireysel fekal numuneler, Nisan 1996 ile Ağustos 1997 arasında 16 ana İsveç mezbahasında toplanmış 3071 fekal örnekten, \% 1.2'lik bir prevalansa işaret eden 37 numunede VTEC O157 bulunmuştur (CI \% 95 0.8-1.6). 37 izolatın tamamının PCR ile belirlendiği üzere verotoksin (VT1 ve / veya VT2), intimin, EHEC-hemolizin ve flagellin H7'yi kodlayan genleri taşıdığ bildirilmiş diğer 3 suşun O157: H7 serotipinde olduğu, fakat verotoksin üretmediği belirtilmiştir. 37 VTEC O157:H7 suşları ayrıca faj tiplemesi ve darbeli alan jel elektroforezi ile karakterize edilmiş olup elde edilen sonuçlar, VTEC O157:H7 taşıyan sığırların yaygınlığının İsveç'teki sığırların genel coğrafi dağılımı ile ilişkili olduğunu göstermiştir. Yapılmış olan bu çalışmanın sonuçları İsveçli sığır çiftçilerine tavsiye edilen bazı özel tedbirlerin temelinin oluşmasına 1şık tutmuş ve kesim konusuyla ilgili olarak İsveç sığırlarında VTEC O157: H7 için kalıcı bir izleme programı başlatılmıştır. (27).

Ülkemizde yapılan bir çalışmada Marmara Bölgesi'nde özel sektöre ve kamu kurumlarına ait süt işletmelerinde bulunan ineklerin dişkı ve sütlerinde, çiftlikte var olan diğer hayvanların (kedi, köpek, vb.) dışkılarında, ayrıca bu işletmelerin bulunduğu alanlardaki çevrede E. coli O157:H7'nin olup olmadığ 1 ve mevsimsel prevalansının bilinmesi için yürütülen çalışmada sonbahar döneminde toplanan 288 örnekten, çevresel alanlardan kaynaklı bir örnekte E. coli O157, dışkı kaynaklı bir örnekte E. coli O157:H7, ilkbahar döneminde ise yine toplam 288 örnekten dışkı kökenli 10 adedinde E. coli O157 tespit edilmiştir. Bu sayede yapılan değerlendirmeler sonrasında yalnızca dışkıda mevsime bağlı olarak E. coli O157:H7 varlığ önemli bulunmuş, etmenin taşınma ve çoğalma yollarına dikkat çekilmiştir (28).

Tokat'ta satışı geçekleştirilen tavuk etlerinin bazı mikrobiyolojik özelliklerinin belirlenmesi amaciyla kasap, market ve bakkallarda satışı gerçekleştirilen tavuk göğsü ve butlarından 25 'er adet örnek alınmış, doğrulama ve tanımlama testleri sonucunda analiz edilen tavuk göğsü örneklerin 21 'inde (\%84) E. coli biyotip 1, 2'sinde (\%8) E. coli biyotip 2, 6'sında (\%24) E. coli O157:H7 bulunduğu tespit edilmiş ayrıca tavuk budu örneklerinin 24'ünde (\%96) E. coli biyotip 1, 2'sinde (\%8) E. coli biyotip 2, 6'sında (\%24) E. coli O157:H7, belirlenmiş olup yapılan bu çalışma doğrultusunda tavuk göğsü ve butlarının mikrobiyal açıdan değerlerin fazla bulunması ve pek çok gıda kaynaklı patojen bakteriyi içermesi sebebiyle halk sağlı̆̆ını riske atan tablo ortaya çıkmıştır (29).

Afyonkarahisar'da tüketime sunulan taze marul örneklerinin mikrobiyolojik kalitesini araştırmak amacıyla yürütülen çalışma doğrultusunda toplam 70 adet taze marul örneği market ve pazarlardan toplanmış olup Escherichia coli O157 ve Listeria monocytogenes varlığ yönünden analiz edilmiştir. ISO 16654 ve ISO 11290-1'e göre gerçekleştirilen analiz 
sonucunda, 70 adet marul örneğinin $2(\% 2,86)$ tanesinde E. coli O157 ve $1(\% 1,43)$ tanesinde de L. monocytogenes tespit edilmiş olup marul örneklerinin patojenleri bulundurduğu ve mikrobiyolojik kalitenin de düşük düzeyde olduğu bildirilmiştir (30).

Gıda ile ilişkili olmayan ortamlarda gıda kaynaklı patojenlerin moleküler ekolojisi ile ilgili bilgi eksikliğini gidermek amacıyla, Kuzey Colorado'daki beş noktadan (bozulmamış doğal ortam) ilkbahar, yaz ve sonbahar mevsimlerinde 2 yıl boyunca örnekler toplanmış minimal antropojenik verilere sahip gıda kaynaklı patojenler bozulmamış doğal ortamlardan izole edilmiştir. Listeria, Salmonella ve Shiga toksin üreten Escherichia coli (STEC)' nin tespiti için toprak, su, sediment, yüzey toprağı ve vahşi yaşam dışkı örnekleri mikrobiyolojik olarak analiz edilmiş ve elde edilen izolatlar alt tiplenmiş olup 3 örnek Listeria monocytogenes için pozitif olarak test edilmiş, 19 örnek diğer Listeria spp., 2 örnekten Salmonella izole edilmiş ancak 5 örnek ise O157 STEC içermiyordu ve E. coli O157:H7 bulunamamıştır. Bozulmamış doğal ortamlarda gıda kaynaklı patojenlerin mevcudiyetinin nadir bulunduğunu, belirli bir doğal alan içerisinde izole edilmiş organizmalar arasında genetik çeşitliliğin olduğunu ve bu konuda Kuzey Colorado iklimi ve topografyasının etkili olduğu bildirilmiştir (31).

Yapılmış olan bazı çalışmalarda, hastalığın bulaşmasında böceklerin de önemli birer vektör olduğu görülmüştür. Laboratuvar koşullarında yapılan araştırmalarda Enterohemorajik Escherichia coli (EHEC) O157:H7'nin ilk olarak Musca domestica L'den izole edildiği kayıtlara geçmiştir. 1997 yılında yürütülen bir araştırmada yaz ve sonbahar mevsimlerinde Hokkaido'daki Obihiro-City'deki 4 farklı çiftlikten toplam 310 sinek örneği toplanmış, örneklerden 5 tanesinin E. coli serotipi O157:H7 taşıdığı tespit edilmiştir. ELISA ve Vero hücre sitotoksisite deneyleri yapılarak elde edilen sonuçlara göre 1 sığır çiftliğinden 3 izolatın hem aktif Shiga-toksin tip 1 (Stx1) hem de 2 (Stx2) ürettiği kayıtlara geçmiştir. Bu çalışmadan elde edilenen sonuçlar ayrıca ev sineklerinin de toksijenik EHEC O157:H7'yi taşıyabildiğini ve bulaşmada birer vektör olduğunu göstermiştir (32). Tarımsal üretim yapılan tarlalara yakın çiftliklerde bulunan özellikle Muscidae ve Calliphoridae familyalarında (hayvan dışkılarında gelişebilmeleri sebebiyle pis sinekler olarak bilinir) bulunan ve hızla çoğalma özelliğine sahip sineklerin E. coli O157:H7'yi hayvanların dışkıları aracılığı ile yeşil yapraklı bitkilere ulaştırdı ̆̆ 1 da kaydedilmiştir (33).

Hasat öncesi dönemde etmenin bulaşma yolları ile ilgili olarak toprak, su, çiftlik gübreleri, evcil ve yabani hayvanlar, hasat işlemini gerçekleştiren çalışanlar ve kullanılan hasat makinelerinin etkili olduğu bilinmektedir (34).

Sebzelerin kesilmesi veya parçalanması ev ortamında kullanılan ekipmanlarla çapraz kontaminasyon riskini artırmaktadır. Escherichia coli O157:H7 ve Listeria monocytogenes transfer (aktarma) hızları (Tr bıçakları ve marul yaprağı kesme arasında) araştırılmış ve yapraklı sebzelerin ardışık kesintileri esnasında bakteriyel transfer açısından bıçakla marul yaprakları arasın yarı mekanik bir model geliştirilmiştir. Her iki patojen açısından da maruldan bıçağa dağılımı düşük olduğu halde aksine eğer kullanılan ekipman etmen ile bulaşıksa bulaşmanın daha yüksek oranda ve daha riskli olabileceği belirtilmiştir. Yapılan bu çalışma ile geliştirilen model sayesinde yeşil yapraklı salataların hazırlanması sırasında risk değerlendirmesinin yapılabilmesi için faydalı bir araç olabileceği düşünülmektedir (35).

Escherichia coli O157:H7' nin modifiye atmosferde paketleme, depolama sıcaklı̆̆ ve süresinin hayatta kalma ve büyüme üzerindeki etkisinin araştırıldığı çalışmada parçalanmış marul, dilimlenmiş salatalık ve rendelenmiş havuç örneklerinde sebzelerin pH değerleri ve 
duyusal özelliklerindeki değişiklikler izlenmiş \% 3 oksijen ve\% 97 azot içeren atmosfer altında ambalajlamanın, E. coli O157:H7 popülasyonu üzerinde belirgin bir etkisinin olmadığ görülmüştür. Ancak canlı E. coli O157:H7 popülasyonları, $5^{\circ} \mathrm{C}$ 'de saklanan sebzelerde azalmış, 12 gün süreyle $21{ }^{\circ} \mathrm{C}^{\prime}$ de saklanan sebzelerde canlı kalma süresinin 14 güne kadar uzadığ 1 gözlenmiştir. E. coli O157:H7 popülasyonlarında en hızlı artışlar, $21^{\circ} \mathrm{C}^{\prime}$ de saklanan marul ve salatalık örneklerinde meydana gelmiştir. Sebzelerin görsel görünümündeki değişiklikler E. coli O157:H7'nin büyümesinden büyük ölçüde etkilenmemiştir. E. coli O157: H7' nin ticari uygulamada işleme ve saklama koşullarına tabi tutulmuş çiğ salata sebzelerinde büyüme kabiliyetinin olduğu gözlenmiştir (36).

Escherichia coli O157:H7'nin neden olduğu su kaynaklı salgınlarda, yeterince klorlanmamış içme sularının kullanılması, kontamine olmuş göl ya da havuzlarda yüzme şeklinde bu patojenin neden olduğu su kaynaklı hastalıklarla ilgili endişeleri artırmaktadır. Yapılan çalışmalar göstermiştir ki E. coli O157:H7' nin suda, özellikle düşük sıcaklıklardaki sularda uzun süre hayatta kalabilen dayanıklı bir patojen olduğunu suda canlı kalabilen fakat kültürlenemeyen (VBNC) bir duruma girebileceğini göstermektedir. Konuyla ilgili olarak 1991 yılında Missouri'de kaynak sularının dezenfeksiyon problemi sebebiyle 243 kişi etkilenmiş, 4 kişi de yaşamını kaybetmiştir. Aynı yıllarda Oregon'da gölde meydana gelen kontaminasyon nedeniyle 21 çocuk enfekte olmuş, Güney Afrika'da da içme ve sulama sularında oluşan kontaminasyon nedeniyle de E.coli O157:H7 vakaları o tarihlerde kayıtlara geçmiştir (37).

Escherichia coli O157:H7'nin hemolitik üremik sendromun (HUS) en önemli nedeni olduğu bilinmektedir. Yapılan çalışmalar, HUS riskinin E. coli O157:H7 filogenetik ağacında farklılık gösterdiğini ortaya koymuştur ancak yaş ile ilişkili rolü tam olarak bilinememektedir. Washington State'de, 2004-2015'te bildirilen 1160 kültür onaylı E. coli O157:H7 vakasından elde edilen izolatların filogenetik soyunu belirleme çalışmaları yapılmıştır. Genelleştirilmiş tahmin denklemlerinin kullanılarak filogenetik soy ve HUS arasındaki ilişkiyi test etmek amacıyla insanlar açısından yaş faktörünün etki değiştirici olarak değerlendirildiği çalışmada 1082 E. coli O157:H7 hem filogenetik soy hem de HUS statüsündeki H7 vakaları (HUS n = 76) yaşa göre etki değişikliği göstermiştir. Soy Ib ile ilişkili bir soy, örneğin IIa $\geqslant 60$ yaşındakilerde tersine etki gözlenirken filogenetik soy, sadece $\geqslant 10$ yaş arasındakilerde HUS riski ile ilişkili görünmektedir. Ib 'ye göre IIa ve IIb de 0-9 yaş arası çocuklarda HUS ile ilişki gözlenmemiş ancak 10-59 yaş arası vakalar için, IIa ve IIb soylarının, Ib soyundan daha fazla HUS riski taşıdığı kaydedilmiştir. 10 yaşından küçük çocuklar arasında, en sık etkilenen yaş grubu olan soy, HUS'la olan ilişkiyi tam olarak açıklayamamaktadır. Bununla birlikte, soy sıklığı yaş grupları arasında değişiklik göstererek maruz kalma ve / veya erken hastalık belirtisinde farklılıklar olduğunu göstermektedir (38). Bakterinin enfeksiyona neden olabilme dozu kesin olarak bilinmeyip, meydana gelen salgınların bulgularına göre, bilinen dozun 10100 organizma gibi oldukça az seviyelerde bulunduğu vurgulanmaktadır $(39,40)$.

Escherichia coli O157:H7 'nin farklı donma noktalarında hayatta kalma ve canlılığının kaybolduğu sıcaklık derecelerini belirlemek amaciyla dört E. coli O157:H7 suşu besinsiz fosfat tamponlu salin (PBS) çözeltisinde $-20{ }^{\circ} \mathrm{C}$ 'de 24,48 ve 72 saat süreyle dondurulduktan sonra, dört suşun hepsinde hücre hasarı ve hatta ölümün meydana geldiği ve şiddetin zamana bağlı olarak suşlar arasında değişkenlik gösterdiği tespit edilmiştir. Dört suşun bir karışımı PBS'de dondurulduktan sonra 20,30 ya da $37^{\circ} C^{\prime}$ de eritildiğinde, hücre ölümü, artan çözülme 
sıcaklığıyla beraber şiddetlenmiş, 72 saat süreyle donmuş E. coli hücrelerinin koloni sayıları, her sıcaklıkta 48 saat çözülme sırasında önemli ölçüde azaldığı gözlenmiştir $(\mathrm{P}<0.05)$. Yavaş çözülme işleminin E. coli O157:H7' nin hayatta kalması üzerindeki etkisini belirlemek için dondurulmuş suşlar farklı süreler boyunca $\left(0,2,6\right.$ ve 12 saat) $4{ }^{\circ} \mathrm{C}$ 'de yavaşça eritilmiş ve 37 ${ }^{\circ} \mathrm{C}$, sırasıyla 5, 10 ve 30 dakika süreyle tutulmuştur. Sonuçlar, daha uzun süre yavaş eritmenin bakteriyel sağ kalım için daha faydalı olduğunu göstermiştir. Dondurulmuş E. coli, $4{ }^{\circ} \mathrm{C}$ de 12 saat / $37^{\circ} \mathrm{C}$ 'de 5-30 dakika boyunca eritilmiş ve sonra sorbitol MacConkey agar (SMAC) üzerinde kültürlenmiştir. Triptoz soy agar (TSA) üzerinde kültürlendikten sonra daha yüksek bakteri sayımları tespit edilmiş, bu da yaralı hücrelerin bulunduğunu göstermiştir. Bu sayede yavaş çözülme işleminin donmuş gıdaların risk değerlendirmesi sırasında hayatta kalan bakterilerin, özellikle de yaralanan bakterilerin tespitlerinin ve kontrollerinin daha fazla dikkat edilmesi gerektiğini göstermiştir (41).

Yeşil yapraklı sebzelerin nakliyesi ve depolanması sırasında sıcaklığın E. coli O157H:7'nin gelişimine olan etkisini belirlemek için paketlenmiş sebzelerde dalgalanan sıcaklıkların mikrobiyal güvenlik ve ürün kalitesini olumsuz etkilediği kaydedilmiştir. 16 aylık süre boyunca, 4 coğrafi bölgeyi kapsayan 5 farklı noktada paketlenmiş yeşil yapraklı sebzeler için bir dizi zaman-sıcaklık profili elde edilmiştir. Yapılan hesaplamalar sonucunda patojenin taşıma ve depolama durumlarında $<2 \log \mathrm{CFU} / \mathrm{g}$ artış gösterdiği bununla birlikte, özellikle depolama sürecinin patojen gelişimini önemli ölçüde etkilediği belirtilmiştr (42).

Konvensiyonel ve organik olarak yetiştirilmiş marulların doğrandıktan sonra Listeria monocytogenes ve Escherichia coli O157:H7 arasındaki etkileşimlerinin değerlendirildiği çalışmada $10 \pm 1{ }^{\circ} \mathrm{C}$ 'de 8 gün süreyle muhafaza edilmesinin deneme süresince az, orta ve çok seviyede olan E. coli'nin gelişmesi ve canlılığ 1 konusunda bir değişim olmadığını göstermiştir. $\mathrm{Bu}$ çalışmadan elde edilen verilerle taze kesilmiş sebzelerin gıda kaynaklı patojenlerle kontaminasyonunu önlemek için düzeltici önlemlerin gerekliliğini vurgulanmıştır (43).

Yenilebilir bitki filizleriyle ilgili sayısız gıda kaynaklı hastalık salgınlarına rağmen, çiğ filizlenmiş tohumların tüketimi İskandinavya'da sağlıklı yaşam tarzıyla bağlantılı olarak oldukça yaygındır. Evde filiz üretimi için farklı fillizlenme modülleri piyasada bulunabilmektedir ve filizlenme konusundaki mevcut riskler hakkında yeterli bilgi sahibi olmadan satışları gerçekleşmektedir. Filizlenme sırasında, koşullar tohum oluşumu için olduğu kadar, aynı zamanda bakteriyel proliferasyon için de ideal olabilmektedir. Ayrıca, filizlenme için kullanılan tohumlar steril olmadığından, insan patojenleri filizlenme modülleri içerisinde çoğalabilmektedirler. Yapılmış olan bu araştırmayla, Escherichia coli suşu O157:H7' nin, ev filizlenmesi amacıyla tasarlanan iki tip üç katmanlı filizlenme modülünde dikey dağılımı değerlendirilmiştir. Organik çemen otu tohumu yapay olarak aşılanmış ve fillizlenme modüllerinin üst veya alt katmanına aktarılmıştır. Kommensal bakteriyel biota yapay olarak sokulan bir suşun săg kalımını etkileyebileceği gibi patojenleri de içerebildiği için, çemen tohumu üzerindeki kültürleştirilebilir bakteri türleri değerlendirilmiştir. Uygulamada üst veya alt tabakadaki tohumlara eklendiğinde, tüketicinin yapay olarak sokulan suşa maruz kalma riskini değerlendirmek için bir Beta-Poisson modeli kullanılmıştır. Aşılanan suşun tabakalar arasında yukarı ve aşağı doğru dağıldığını ve bakteriyel dağılma riskinin her iki yönde de yüksek olduğunu ve ayrıca tüketicilerinde patojenlerle karşı karşıya kalma tehlikesinin de yüksek olduğu bu sayede tespit edilmiştir (44). 
Oman'da yapılmış olan bir çalışmada da incelenen 105 adet ithal taze meyve ve sebze örneklerinin \%22'sinde, meyve örneklerinin de \%7' inde E. coli tespit edilmiş ayrıca bu çalışma sayesinde ürünlerin E. coli ile bulaşık olması sebebiyle ithalat ve ihracaat açısından uluslararası bir tehtidin söz konusu olduğu kanaatine de varılmıştır (45).

\section{Klinik Belirtiler}

Halk sağlığı açısından neden olduğu kaygı verici olumsuzluklar sebebiyle önemli bir patojen olan Escherichia coli O157:H7 ilk olarak 1982 yılında fast food zincir restoranlarında yeterince pişirilmemiş hamburger etinin tüketilmesi sonucu oluşan kanlı ishal sebebi olarak kayıtlara geçmiştir $(46,47,48)$. Hastalıkla ilgili septomlar şiddetli karın ağrısıyla başlar ilk etapta sulu sonrasında kanlı diareye dönüşmektedir. E. coli O157:H7 genellikle 2-4 gün süreyle kramplı karın ağrısı, mide bulantısı, gastroenteritis, kanlı diare gibi semptomlara neden olur bazende tam tersi olarak herhangi bir semptom vermeden ya da orta şiddetli diareler şekinde varlığını sürdürebilmektedir (49).

E. coli O157:H7 serotipi diyare haricinde insanlarda 3 çeşit sendromada sebep olabilmektedir. $(50,51)$.

Hemorajik Kolitis (HC): Enfeksiyonun başlangıcı oldukça kuvvetli karın ağrısı ve sulu ishal şeklinde olup üçüncü günün sonrasında kanlı ishale dönüşmektedir. Enfeksiyon süresi yaklaşık 2-9 gün olabilmektedir $(50,51,52,53)$. HC'li hastaların yaklaşık olarak \% 10 'u, akut böbrek yetmezliği, hemolitik anemi ve trombositopeni ile E. coli O157: H7'nin yaşamı tehdit eden bir komplikasyonu olan hemolitik üremik sendrom (HUS) gelişmektedir (39).

Hemolitik Üremik Sendrom (HUS): Küçük çocuklar ve yaşlilar riskli grup olarak kabul edilir, çocuklarda akut böbrek yetmezliğinin sebebi olarak bilinir. HUS belirtisi gösteren hastalarda akut renal yetmezlik, trombositopeni ve mikroanjipatik hemolitik anemiyi takip eden diyare oluşur ve böyle durumlarda \% 5-10 oranında ölümle sonuçlanan olaylar gözlenebilmektedir $(51,52)$. E. coli infeksiyonlarının epidemiyolojisinin bilinmesi HUS hastaları için geliştirilmiş spesifik bir tedavi yöntemi olmadı̆̆ 1 için önem teşkil etmektedir (55).

Trombotik Trombositopenik purpura (TTP) : Yetişkin insanlarda daha sık görüen bir durum olup HUS benzeri klinik belirtiler göstermektedir. Genel olarak HUS'tan farkı gözlenen nörolojik belirtiler daha yüksek olup beyinde meydana gelen kan pihtıları sebebiyle ölüm oranının yüksek oluşudur $(50,51)$.

Ancak tüm bunların dışında hastalar yaşamlarını sürdürseler de, hastalığın seyri böbrek yetmezliği şeklinde gelişmekte ve hayatlarının geri kalan dönemlerini diyaliz makinesine bağ l $_{1}$ olarak devam ettirebilmektedirler (56).

\section{Korunma ve Kontrol}

Enfeksiyonu engellemek adına üretimden, gıdaların işlenmesine, hazırlanmasından dağıtım zincirine kadar olan tüm zaman diliminde izlenebilirlik sağlanmalı her türlü kontrol önlemleri alınmalıdır. Pastörizasyon konusu önemli olduğu için süt ürünleri ve meyve sularının tüketimine dikkat edilmeli ve yeteri kadar pişirilmemiş et ürünleri özellikle hamburgerlerin tüketiminden uzak durulmalıdır. Ülkemizde yaygın olarak tüketilen geleneksel et ürünlerinin başında Türk tipi sucuk ve pastırma gelmektedir. Bu nedenle İstanbul, Adapazarı, Afyon ve Kayseri'de yürütülen bir çalışmada üreticiler ve perakende satış yerlerinden alınan 132 adet 
sucuk ve 66 pastırma örneğinde Salmonella spp. \% 2.52 ve L. monocytogenes \% 2.02 olarak tespit edilmiş ancak alınan örneklerin hiç birinde E. coli O157'ye rastlanmamıştır (57). Yaprakları taze olarak tüketilen filizlerin sebze ve meyvelerin birer inokulum kaynağı olması nedeniyle temiz yıkandığından emin olunmalı ve hijyen sağlanmalıdır. Sulama konusunda özellikle meyve ve sebzelerin sulanmasında kullanılan suların temiz su olmasına atık su ya da kirli su olmamasına dikkat edilmelidir. Çiftlik gübrelerinin kullanımı konusunda dikkatli olunmalı, çevrede bulunan çiftlikler ve hayvanların olduğu alanlara yakın yerlerde bulunan sularda yüzülmemelidir. Söz konusu patojen, asitlere karşı dayanıklı olduğundan dolayı fermente ürünlerde ve taze olarak tüketilen gıdalarda canlılığını sürdürebilmektedir. Küçük çocuklar ve yaşlı bakım merkezlerinde yaşayanlar riskli grup olduklarından kişiden kişiye bulaşma daha kolay olabilmektedir ve bu anlamda konunun öneminden dolayı gerekli tedbirler alınmalıdır. Salgınlarda klinik belirti görülmeksizin patojen taşıyan personel de etmenin bulaşmasında etkili olabilmektedirler (58).

Marul dahil yeşil yapraklı sebzelerin gıda kaynaklı hastalıklardan Escherichia coli O157:H7 için potansiyel risk oluşturması sebebiyle kantitatif mikrobiyal risk değerlendirmeleri (QMRA), gıda kaynaklı patojenlerle ilişkili potansiyel riskleri değerlendirmek ve kontrol altına almak için etkin bir yol olarak görüldüğünden taze kesilmiş marulda E. coli O157:H7 için bir QMRA modeli geliştirmiş ve farklı potansiyel müdahale stratejilerinin halk sağlığı risklerinin azaltılmasındaki etkileri değerlendirilmiştir. Yapılan işlem taze kesilmiş marul üretimi ve tedarik zinciri, tarla üretiminden hem sulama suyu hem de ilk kontaminasyon kaynağ 1 olarak bilinen toprak ile evde tüketim durumuna göre modellenmiștir. Temel model ABD'de 10 milyon porsiyon başına ortalama 1 hastalık ve yılda ortalama 2, 16 hastalık vakası olduğu tahmin edilmiş ve değerlendirme sonrasında tüm müdahale stratejileri (klor, ultrason ve organik asit, 1şınlama, bakteriyo faj ve tüketici yıkama), bazal model öngörüsüyle karşılaştırıldığında tahmini ortalama hastalık vaka sayısını (11,4 - 17,9 kat azaltma) önemli ölçüde azalttığı gözlenmiştir. Duyarlılık analizleri; perakende ve ev depolama sıcaklığını, öngörülen hastalık vakalarını etkileyen önemli faktör olarak belirtmiştir. Geliştirilen QMRA modeli, etmen ile bulaşık taze kesilmiş marul tüketimi ile ilgili riskleri tahmin etmek için bir çerçeve sunmuş ve bu riski azaltmayı amaçlayan müdahale stratejilerinin değerlendirilmesine ve geliştirilmesine rehberlik edebileceği belirtilmiştir (59).

Kiraz domateslerde (Cherry domates) E. coli O157:H7 gelişimini engellemek ve kontrol altına almak için bakteriyofajların biyo-dezenfektanlar olarak kullanımını değerlendirmeyi amaçlayan bir çalışmada bu patojene karşı spesifikliği olan fajlar çoğaltılıp, titre edilip ve transmisyon elektron mikroskobu ile karakterizasyonu yapılmış ve ayrıca izole fajların, sanitizasyon işleminden sonra domateslere daha sonra uygulanabilmesi için uygulanabilirliği de belirlenmiştir. E. coli O157:H7' nin viral partiküllerin varlığında veya yokluğunda ve izole edilen fajların litik spektrumunda in vitro davranışları da belirlenmiş ayrıca gıda seköründe sıkça kullanılan bir bakteriyofajlar havuzunun ve bazı kimyasal dezenfektanların etkisi, E. coli O157:H7'nin gelişimi açısından karşılaştırılmış ve ömürleri arttırıcı maddeler olarak potansiyelleri, oda sıcaklığında saklanan domatesler için değerlendirilmiştir. Bakteriyofajlar 10 ^ 9 ila $10^{\wedge} 14 \mathrm{PFU} / \mathrm{mL}$ arasında değişen yüksek konsantrasyonlara ulaşmış ve ağırlıklı olarak Escherichia cinsine özgü olduğu gözlenmiş, Salmonella, Pseudomonas, Enterobacter ve Enterococcus için litik bir aktivite göstermemiştir. E. coli O157:H7'nin gelişmesinde bakteri havuzlarının temizleyici etkisi ile kimyasal temizleyicilerin arasında belirgin bir farklılık tespit 
edilmemmiş olup in vitro analizler sayesinde, bakteriyofajların mikrobiyal büyümeyi önemli ölçüde azalttığını ve bu nedenle biyolojik dezenfektanlar olarak potansiyel olduğunu göstermiştir ( 60).

Taze kesilmiş marul ve semizotu örneklerinde Salmonella typhimurium ve Escherichia coli 0157:H7 canlılı̆̆ının belirlenmesi, bu duruma olan antimikrobiyal etkilerinin tespit edilmesi amaciyla da dezenfeksiyon işlemleri için $0.01 \mathrm{ml} / \mathrm{L}, 0.032 \mathrm{ml} / \mathrm{L}$ veya $0.08 \mathrm{ml} / \mathrm{L}$ konsantrasyonlarında nane ve fesleğen esansiyel yağları kullanılmıştır. Dezenfekte olan örnekler aerobik koşullarda paketlenmiş ve $+4^{\circ} \mathrm{C}$ 'de 7 gün süreyle saklanmıştır. Elde edilen sonuçlar 1şığında nane esansiyel yağı, fesleğen esansiyel yağına kıyasla patojenler üzerinde daha fazla antimikrobiyal etkide bulunmuştur. Ayrıca iki ayrı sebzede de patojenlere karşı en etkin antimikrobiyal etki $0.08 \mathrm{ml}$ / L konsantrasyonunda bulunmuştur (61).

Temizlenmiş ve doğranmış marul, iceberg marul, ıspanak ve lahana sebzeleri üzerine L.monocytogenes, S.aureus, E.coli, S. typhimurium ve B.cereus inoküle edilmiş 5, 10, ve 15 dakika süreyle sırayla 2,5 ve 10 ppm ozon gazlamasıyla yıkama uygulamasının etkisi ve bu uygulama sonrasında sebzelerde oluşabilecek renk değişimlerinin incelendiği çalışmada, uygulama yapılan tüm sebze örneklerinde mikrobiyal yükte bir azalmanın gerçekleştiği görülmüş ozon konsantrasyonu ve uygulama süresi artırıldıkça sebze örneklerindeki mikroorganizma miktarında da zamana bağlı olarak azalma gözlenmiştir. Uygulamada en yüksek mikrobiyal etki 10 ppm konsantrasyonunda $15 \mathrm{dk}$ 'lik uygulamalarda belirlenmiş olup 2, 5 ve $10 \mathrm{ppm}$ konsantrasyonlarında ozonlu su uygulamasının sebzeler üzerinde renk değişimleri konusunda istatistiksel olarak önemli bir değişikliğe neden olmadığ 1 belirtilmiştir (62).

\section{SONUÇ}

E. coli O157:H7 enfeksiyonlarının önlenebilmesi ve patojenlerin bulaşma riskini azaltmak için öncelikli olarak çiftlik gübrelerinin kullanımına dikkat edilmeli gübreyle bulaşma yollarını minimum düzeye düşürmek amacıyla hayvancılık uygulamalarında düzenlemeler (hayvanların beslenme sistemleri, sağlık kontrolleri, cins tercihi) yapılması uygulanacak yöntemlerin başında gelebilir. E. coli O157:H7 enfeksiyonlarına karşı tedbir almak amacıyla özellikle kesim işlemleri sırasında hijyen kurallarına ve ilgili prosedürlere (örneğin; soğuk zincir, saklama koşulları...) dikkat edilmeli, et ve et ürünlerinden hazırlanan gıdalar iyice pişirilmeli, meyve suları, süt ve süt ürünleri pastörize edilmelidir. Gıda işletmelerinde ve üretim tesislerinde Tehlike analizi kritik kontrol noktası (HACCP) kuralları uygulanmalıdır. Bunun yanı sıra bulaşma riski yüksek olan sebzeler içinde temizlik konusuna dikkat çekilmelidir. Vektör böceklerle mücadele ve yabancı ot mücadelesi konusuna da önem verilmeli, hasat sırasında kullanılan alet ekipmanın hayvan gübresi ile kontamine olmamasına özen gösterilmelidir. Enfeksiyonun oluşumu ve önlenebilmesi adına hastanelerde, yaşlı ve çocuk bakım merkezlerinde, gıda işletmelerinde ve besinlerin tüketime hazırlanmasında görev alan personel düzenli olarak dönem dönem eğitime alınmalıdır. Kullanma sularının özellikle içme sularının mikrobiyolojik kalitesi kontrol edilip hijyen ve kalitesine dikkat edilmelidir. Ayrıca kontamine olmuş göl ve sularda yüzülmemesine özen gösterilmelidir. 
Kontaminasyon oluşumuna zemin hazırlayan sebeplerin bilinmesi, yaşanabilecek olumsuzlukların riskini azaltmayı amaçlayan proseslerin ve teknolojilerin geliştirilmesine katkı sağlayacaktır).

\section{Çıkar Çatışması}

Yazarlar arasında çıkar çatışması yoktur.

\section{KAYNAKLAR}

1. Chaudry, M.A., Bibi, N., Khan, M., Khan, M., Badshah, A., Qureshi, M.J. (2004). Irradiation treatment of minimally processed carrots for ensuring microbiological safety. Radiation Physics and Chemistry, 71, 169-173.

2. Seow, J., Agoston, R., Phus, L., Yuk, H. (2012). Microbiological quality of fresh vegetables and fruits sold in Singapore. Food Control, 25, 39-44.

3. Leichert LI. (2011) Proteomic methods unravel the protein quality control in Escherichia coli. Proteomics, 11: 3023- 3035.

4. Baysal B. Escherichia coli. İçinde: Cengiz T, Mısırlıgil A, Aydın M (editörler). Tıp ve Diş Hekimliğinde Genel ve Özel Mikrobiyoloji, 1. Bask1. Ankara, Güneş Kitabevi, 2004: 454- 458.

5. Erdem B. Enterobacteriaceae. İçinde: Ustaçelebi Ş, Mutlu G, İmir T, Cengiz T, Tümbay E, Mete Ö (editörler). Temel ve Klinik Mikrobiyoloji, 1. Baskı. Ankara, Güneş Kitabevi, 1999: 480- 485.

6. Şahin İ, Başoğlu B. Gıda Mikrobiyolojisi, 2. Baskı. Bursa, Dora Basım- Yayın- Dağıtım Ltd. Şti., 2011: 34- 38.

7. Bilgehan H. Klinik Mikrobiyoloji Özel Bakteriyoloji ve Bakteri Enfeksiyonlart (Uygulama Konuları İle), 10. Baskı. İzmir, Barış Yayınları Fakülteler Kitabevi, 2000: 1 - 16.

8. Levinson, W. (2008). Tıbbi Mikrobiyoloji ve İmmünoloji. Ankara: Öncü Basımevi, 136-140.

9. Anonim (2015). http://www.cfsan.fda.gov/ mow/chap15.html. (Erişim Tarihi: 8 Mart 2015).

10. Chapman, P. A., Siddons, C. A., Wright, D. J., Norman, P., Fox, J., Crick, E. (1993). Cattle as a Possible Source of Verocytotoxin-Producing E.coli O157:H7 Infections in Man. Epidemiol. Infect., 111, 439-447.

11. Hilborn, E. D., Jonathan, H., Mermin, H., Patricia, A., Mshar, P.A., James, L., et al. (1999). A multistate outbreak Escherichia coli O157 H7 infections associated with consumption of mesculun lettuce. Archives of Internal Medicine, 59, 1758-1764.

12. Şahin, C. (2005). Gastroenteritli Olgularda E. coli O157:H7 Serotipinin Araştırılması. Cumhuriyet Üniversitesi Sağl1k Bilimleri Enstitüsü, Sivas.

13. Karapınar, M., Gönül, S. A. (1998) Gıda kaynaklı hastalıklar. İçinde: Ünlütürk A, Turantas F. Glda Mikrobiyolojisi, 1. Bask1. İzmir, Mengi Tan Basımevi, 109- 164.

14. Kudva, I. T., Hatfield, P. G., Hovde, C. J. (1996). Escherichia coli O157: H7 in microbial flora of sheep. Journal of Clinical Microbiology, 34: 431- 433.

15. Çiçek E, Savaşan S. (2010). Ege Bölgesi’ndeki sığırların süt ve dışkı örneklerinden escherichia coli O157:H7 izolasyonu ve verotoksinlerinin belirlenmesi. Etlik Veteriner Mikrobiyoloji Dergisi, 21: 51- 56. 
16. Chapman, P. A., Siddons, A., Wright, D. J., Norman, P., Fox, J., Crick, E. (1993). Cattle as a possible source of verocytotoxin-producing Escherichia coli $\mathrm{O} 157 \mathrm{H} 7$ infections in man. Epidemiology of Infection, 111, 439-447.

17. Campbell, G. A., Mutharasan, R. (2004). Detection of pathogen escherichia coli O157: H7 using self-excited PZT-glass microcantilevers. Biosensors Bioelectronics, 15: 7582.

18. Abdul-Raouf, U. M., Ammar, M. S., Beuchat, L. R. (1996). Isolation of escherichia coli O157:H7 from some egyptian foods. Food Microbiology, 29: 423- 426.

19. Conedera, G., Dalvit, P., Martini, M., Galiero, G., Gramaglia, M., Goffredo, E., et al. (2004). Veretotoxin-producing Escherichia coli O157 in minced beef and dairy producs in Italy, International Journal of Food Microbiology, 96: 67-73.

20. Chapman, P. A., Cerdan Malo, A. T., Ellin, M., Ashton, R., Harkin, M. A. (2001). E.coli O157 in cattle, and sheep at slaughter, on beef and lamb carcasses and in raw beef and lamb products in South Yorkshire, International Journal of Food Microbiology, 64: 139- 150.

21. Hilborn, E. D., Jonathan, H., Mermin, H., Patricia, A., Mshar, P.A., James, L., et al. (1999). A multistate outbreak Escherichia coli O157 H7 infections associated with consumption of mesculun lettuce. Archives of Internal Medicine, 59, 1758-1764.

22. Seow, J., Agoston, R., Phus, L., Yuk, H. (2012). Microbiological quality of fresh vegetables and fruits sold in Singapore. Food Control, 25, 39-44.

23. Meng, J., Doyle, M. P. (1998). Emerging and evolving microbial foodborne pathogens. Bulletin Institute of Pasteur, 96, 151-154.

24. Anonim (2018): Marula bağlı E. coli salgını Amerika'da ölümlere neden oluyor. https://doktorumnedio.com/enfeksiyon-hastaliklari/marula-bagli-e-coli-salginiamerikada-olumlere-neden-oluyor/ (Erişim Tarihi: 8 Haziran 2018).

25. Berger, C. N., Sodha, S. M., Shaw, R. K., Griffin, P. M., Pink, D., Hand, P., et al. (2010). Fresh fruit and vegetables as vehicles for the transmission of human pathogens. Environmental Microbiology, 12(9), 2385-2397.

26. Rocchi, G., Capozzi, M. (1999). Enterohemorrhagic Escherichia coli O157:H7 infection, Recenti Prog Med, 90(11), 613-618.

27. Albihn, A., Eriksson, E., Wallen, C., Aspán, A. (2003). Verotoxinogenic Escherichia coli (VTEC) O157:H7 - A Nationwide Swedish Survey of Bovine Faeces. Acta Veterinaria Scandinavica, 44, 43-52.

28. Birdal, E., AK, S. (2018). Marmara Bölgesi'ndeki süt işletmelerindeki ineklerde ve çevrede E. coli O157:H7 varlığının saptanması. Anadolu Çevre ve Hayvancılık Bilimleri Dergisi, 3(2), (85-90).

29. Yıldırım, Z., Ceylan, Ş., Öncül, N. (2015). Tokat piyasasında satışa sunulan tavuk etlerinin mikrobiyolojik kalitesinin belirlenmesi. Akademik Glda, 13(4), 304-316.

30. Kara, R., Acaröz, U., Gürler, Z., Soylu, A., Küçükkurt O. (2019). Taze Marul Örneklerinde Escherichia coli O157 ve Listeria monocytogenes Varlığının Belirlenmesi. Avrupa Bilim ve Teknoloji Dergisi, (16), 871-873.

31. Ahlstrom, C. A., Manuel, C. S., Den Bakker, H. C., Wiedmann, M., Nightingale, K. K. (2017). Molecular ecology of Listeria spp., Salmonella, Escherichia coli O157:H7 and non-O157 Shiga toxin-producing E. coli inpristine natural environments in Northern Colorado. Journal of Applied Microbiology, 124, 511-521.

32. Iwasa, M., Makino, S., Asakura, H., Kobori, H., Morimoto, Y. (1999). Detection of Escherichia coli $\mathrm{O} 157 \mathrm{H} 7$ from Musca domestica (Diptera: Muscidae) at a cattle farm in Japan. J. Med. Entomol., 36, 108-112.

33. Talley, J. L., Wayadande, A. C., Wasala, L. P., Gerry, A. C., Fletscher, J., DeSilva, U., et al. (2009). Association of Escherichia coli O157 H7 with filth flies (Muscidadae and 
Calliphoridae) captured in leafy greens fields and experimental transmission of Escherichia coli $\mathrm{O} 157 \mathrm{H} 7$ to spinach leaves by house flies (Diptera: Muscidae). Journal of Food Protection, 72, 1547-1552.

34. Dallaire, R., Vasseur, L., Leblannc, D. I., Tranchant, C. C., Delaguis, P. A. (2006). Methodological approach for assessing the microbial contamination of fresh produce from harvest to retail. Food Protection Trends, 2, 218-225.

35. Zilelidou, E. A., Tsourou, V., Poimenidou, S., Loukou, A. (2015). Modeling transfer of Escherichia coli $\mathrm{O} 157 \mathrm{H} 7$ and Listeria monocytogenes during preparation of fresh-cut salads: Impact of cutting and shredding practices. Food Microbiology, 45, 254-265.

36. Abdul-Raouf, U. M., Beuchat, L. R., Ammar, M. S. (1993). Survival and growth of Escherichia coli $\mathrm{O} 157 \mathrm{H} 7$ on salad vegetables. Applied and Environmental Microbiology, 59, 1999-2006.

37. Wan, G., Doyle, M. P. (1998). Survival of enterohemorrhagic E.coli O157 H7 in water. Journal of Food Protection, 61(6), 662-667.

38. Tarr, G. A. M., Shringi, S., Oltean, H. N., Mayer, J., Rabinowit, P., Wakefield, J., et al. (2018). Importance of case age in the purported association between phylogenetics and hemolytic uremic syndrome in Escherichia coli O157:H7 infections. Epidemiology and Infection, 146, 1550-1555.

39. McCarthy, J., Holbrook, R., Stephens, P. J. (1998). An improved direct method for the enumeration of stressed E.coli O157:H7 from food. J.Food Prot., 61(9), 1093-1097.

40. Peacock, E., Jacob, V. W., Fallone, S. M. (2001). E.coli O157:H7: Ethiology,Clinical Features, Complications, and Treatment. Nephrology Nursing Journal, 28(5), 547-554.

41. SaiSai, J., XianJing, W., JingJing, M., XiaoYan, J., HuanYun, Y., JinLong, T., et al. (2018). Survival of frozen Escherichia coli O157:H7 after thawing. Shipin Kexue / Food Science, 39(6), 82-87.

42. Zeng, W., Vorst, K., Brown, W., Marks, B., Sanghyup, J., Perez-Rodrigez, F., et al. (2014). Growth Escherichia coli O157 H7 and Listeria monocytogenes in packaged fresh-cut romaine mix at fluctuating temperatures during commercial transport retail storage and display. Journal of Food Protection, 77(2), 197-206.

43. Oliveira, M., Vinas, I., Anguera, M., Abadias, M. (2012). Fate of Listeria monocytogenes and Escherichia coli $\mathrm{O} 157 \mathrm{H} 7$ in the presence of natural background microbiota on conventional and organic lettuce. Food Control, 25, 678-683.

44. Mulaosmanovic, E., Farkas, S., Vågsholm, I., Darlison, J., Sousa, M., Mogren, L., et al. (2019). Safety risks associated with dispersal of E. coli O157:H7 in home sprouting modules. Food Science and Technology, 101, 783-788.

45. Al-Kharousi, Z. S., Guizani, N., Al-Sadi, A. M., Al-Bulushi, I. M. and Shaharoona B. (2016). Hiding in fresh fruits and vegetables: Opportunistic pathogens may cross geographical barriers. Hindawi Publishing Corporation International Journal of Microbiology, Article ID 4292417, 14 pages http://dx.doi.org/10.1155/2016/4292417.

46. Öz, F., Kaya, M., Aksu. M. (2002). Sucuk üretiminde farklı nitrit dozlarının ve starter kültür kullanımının Escherichia coli O157:H7'nin gelişimi üzerine etkisi. Turkish Journal of Veterinary and Animal Science; 26: 651-657.

47. Varela-Hernández, J. J., Cabrera-Diaz, E., Cardona-López, M. A., Ibarra-Velázquez, L. M., RangelVillalobos, H., Castillo, A., et al. (2007). Isolation and characterization of Shiga toxin-producing Escherichia coli O157:H7 and non-O157 from beef carcasses at a slaughter plant in Mexico. International Journal of Food Microbiology, 113, 237-241.

48. Park, S., Worobo, R., Durst, R. (2010). Escherichia coli O157:H7 as an emerging foodborne pathogen: A Literature Review. Critical Reviews in Food Science and Nutrition, 39(6), 481-502. 
49. Pedritis, H., Kidder, G., Ogram, A. (2002). E.coli O157:H7, A potential healt concern. University of Florida, 1-4

50. Ünlütürk, A., Turantaş, F. (1998). Gıda Mikrobiyolojisi, 1. Basım, Mengi Tan Basımevi, İzmir.

51. Dunn, J. R. (2003). The Epidemiology of Shiga - Toxigenic Escherichia coli O157:H7 in Louisiana Dairy Cattle, Beef Catle and White - Tailed Deer.

52. Boerlin, P., Mceven, S. A., Petzold, F. B., Wilson, J. B., Jhonson, R. P., Gyles, C. L. (1999). Associations Between Virulence Factors of Shiga Toxin-Producing Escherichia coli and Disease in Humans, Journal of Clinical Microbiology, 37(3), 497-503.

53. Tsai, W. L., Miller, C. E,. Richter, E. R. (2000). Determination of the Sensitivity of a Rapid Escherichia coli O157:H7 Assay for Testing 375-Gram Composite Samples, Applied and Environmental Microbiology, 66(9), 4149-4151.

54. Reilly, A. (1998). Prevention and control of enterohaemorrhagic Escherichia coli (EHEC) infections: memorandum from a WHO meeting. WHO Consultation on Prevention and Control of Enterohaemorrhagic Escherichia coli (EHEC) Infections, Bulletin of the World Health Organization, 76(3), 245-255.

55. Wang, G., Clark, C. G., Rodgers, F. G. (2002). Detection in Escherichia coli of the Genes Encoding the Major Virulance Factors, the Genes Defining the O 157:H7 Serotype and Components of the Type 2 Shiga Toxin Family by Multiplex PCR, Journal of Clinical Microbiology, 40(1), 3619-3619.

56. Bolton, D. J, Ennis, C., Brain, B., Monaghan, A. (2009). Serogroups and virulence genes in verocytotoxigenic Escherichia coli on beef farms and in the beef abattoir. An international conference organised by ProSafeBeef, March 25th to 26th, Dublin, Advancing Beef Safety through Research and Innovation, p: 59.

57. Büyükünal, S. K, Şakar, F. Ş, Turhan, .İ, Erginbaş, Ç., Sandıkçı, Altunatmaz, S., Y1lmaz, Aksu, F., ve ark. (2016). Presence of Salmonella spp., Listeria monocytogenes, Escherichia coli $\mathrm{O} 157$ and Nitrate-Nitrite Residue Levels in Turkish Traditional Fermented Meat Products (Sucuk and Pastırma). Kafkas Univ Vet Fak Derg, 22(2), 233 236.

58. Reilly, A. (1998). Prevention and control of enterohaemorrhagic Escherichia coli (EHEC) infections: memorandum from a WHO meeting. WHO Consultation on Prevention and Control of Enterohaemorrhagic Escherichia coli (EHEC) Infections, Bulletin of the World Health Organization, 76(3), 245-255.

59. Pang, H., Lambertini, E., Buchanan, R.L, Schaffner, D.W, Pradhan, A.K. (2017). Quantitative microbial risk assessment for Escherichia coli $\mathrm{O} 157: \mathrm{H} 7$ in fresh-cut lettuce. Journal of Food Protection, 80(2), 302-311.

60. Lopez, M. E. S., Gontijo, M. T. P., Batalha, L. S, Mendonça, R. C. S (2018) . BioSanitization Using Specific Bacteriophages to Control Escherichia coli O157:H7 in Cherry Tomatoes. Advance Journal of Food Science and Technology, 16, 92-101.

61. Karagözlü, N., Ergönü,1 B., Özcan, D. (2011). Determination of antimicrobial effect of mint and basil essential oils on survival of Escherichia coli $\mathrm{O} 157 \mathrm{H} 7$ and $S$. typhimurinum in fresh-cut lettuce and purslane. Food Control, 22, 1851-1855.

62. Tümay, M. (2019). Ozonun, bazı yeşil yapraklı sebzelerde antibakteriyel etkisinin belirlenmesi. Nevşehir Hacı Bektaş Veli Üniversitesi Fen Bilimleri Enstitüsü, Nevşehir. 